\title{
PROMPT: A prospective study to assess efficacy and safety of metyrapone in endogenous Cushing's syndrome
}

Nieman $L^{1}$, Akinci B², Beckers $A^{3}$, Bolanowski $M^{4}$, Hanzu FAㄴ, Mezôsi E ${ }^{6}$, Tönjes $A^{7}$, Bostnavaron $M^{8}$, Jaspart $A^{8}$, Borensztein $\mathrm{P}^{8}$, Boscaro $\mathrm{M}^{9}$, Scaroni $\mathrm{C}^{9}$

\section{INTRODUCTION}

Metyrapone blocks cortisol production by inhibiting 11ß-hydroxylation of 11-deoxycortisol, the last step of cortisol synthesis (Figure 1).

Based on observational retrospective studies published over more than 50 years, metyrapone is approved for the treatment of endogenous Cushing's syndrome (CS) in 15 European countries.

PROMPT is the first prospective study to document the safety and efficacy of metyrapone using modern assay techniques.

Figure 1: Mode of action of metyrapone

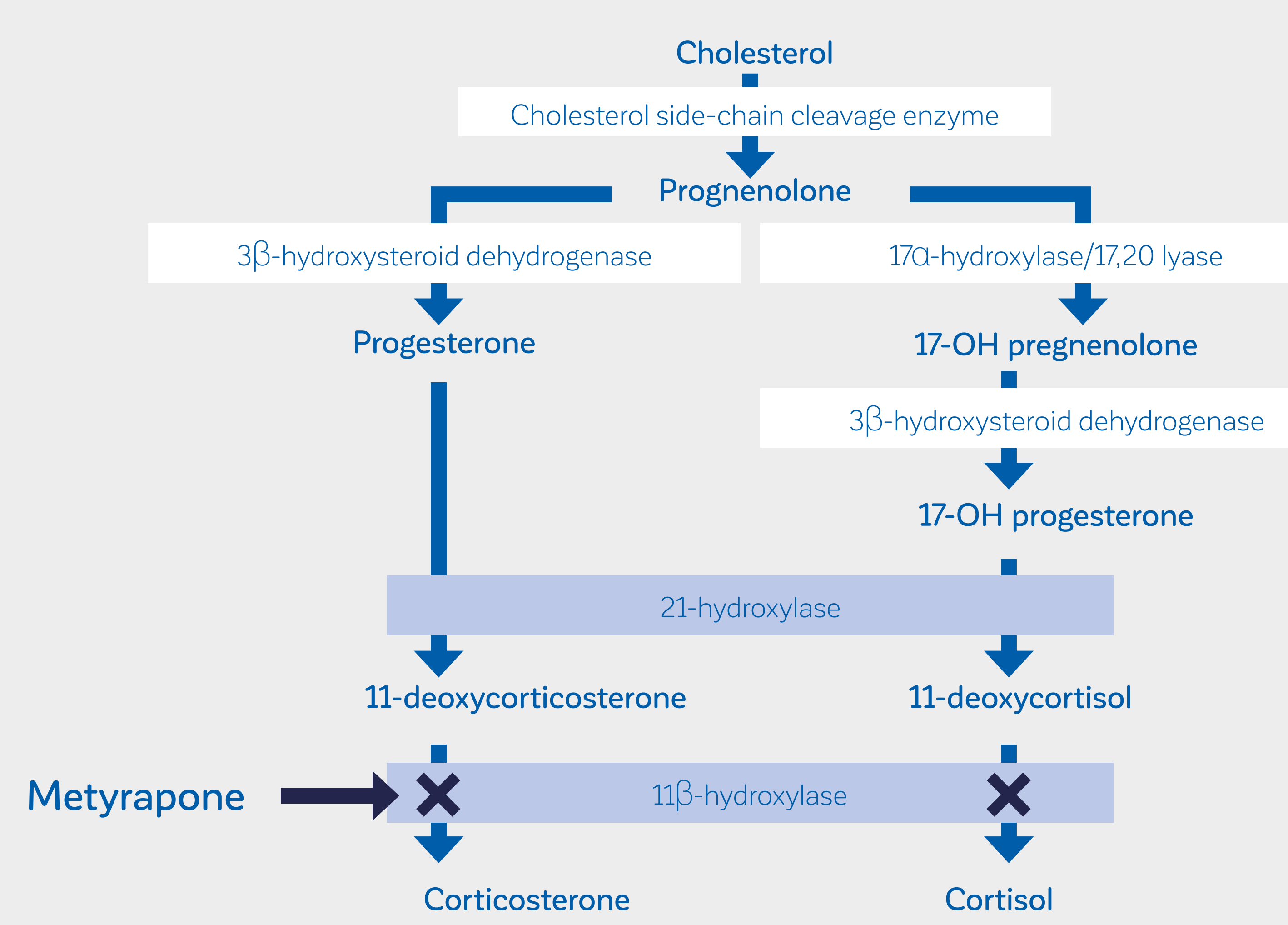

\section{METHODS}

\section{Patients}

Adult patients with a new diagnosis of endogenous CS of any etiology (except advanced adrenal carcinoma) or recurrent or persistent Cushing's disease (CD) after transsphenoidal surgery (TSS), were eligible if three
baseline urinary free cortisol (UFC) values measured over 24 hours were at least $50 \%$ above the upper limit of normal $(U L N=165 \mathrm{nmol} / 24 \mathrm{~h})$.

Study design (Figure 2)

- The international European Phase III/IV PROMPT study commenced in 2015 (ClinicalTrial.gov registry: This single arm, open-label, multicenter trial is ongoing in seven countries:

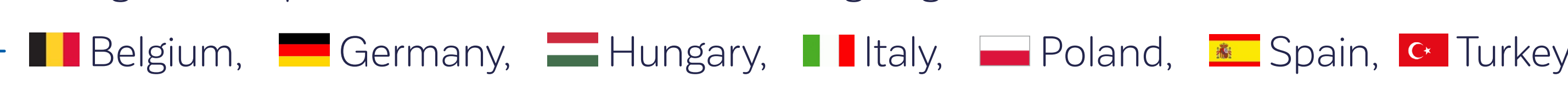

Figure 2: Study design

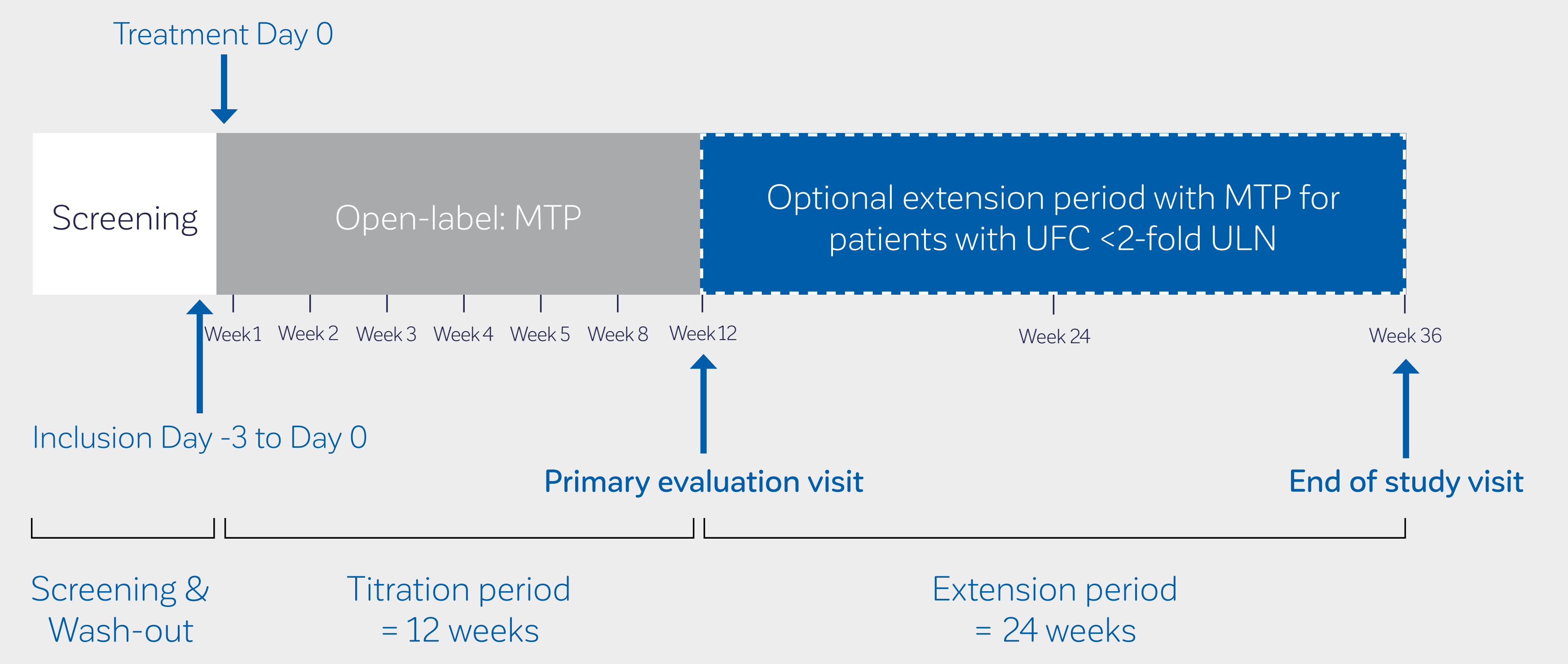

Metyrapone given three or four times daily was individually titrated based on cortisol levels in urine and serum over 12 weeks to achieve normal urine and serum cortisol levels according to a titration scheme (Figure 2). After 12 weeks, patients whose mean value of 3 UFCs (mUFC) was less than twice the ULN, continued to receive metyrapone for another 24 weeks (Figure 2).

Cortisol was measured in a central laboratory by liquid chromatography tandem-mass spectrometry (LC-MS/MS) method. This assay is used to avoid cross-reactivity of11-deoxycortisol incoltisolinm noassays.
Table 1: Metyrapone titration scheme

\begin{tabular}{|c|c|c|c|c|}
\hline \multirow[t]{2}{*}{ Baseline UFC } & \multirow{2}{*}{$\begin{array}{l}\text { Initial MTP } \\
\text { dose }\end{array}$} & \multicolumn{3}{|l|}{ MTP dose change } \\
\hline & & $\begin{array}{l}\text { UFC }>\text { ULN } \\
(165 \mathrm{nmol} / 24 \mathrm{~h}) \\
\text { Or } \\
\text { Morning serum } \\
\text { cortisol >330 nmol/L }\end{array}$ & $\begin{array}{l}\text { Serum cortisol } \\
<193 \mathrm{nmol} / \mathrm{L} \\
\text { Or } \\
\text { Signs/symptoms of } \\
\text { adrenal insufficiency }\end{array}$ & $\begin{array}{l}\text { UFC } \leq \text { ULN } \\
(165 \mathrm{nmol} / 24 \mathrm{~h}) \\
\mathrm{Or} \\
193 \mathrm{nmol} / \mathrm{L} \leq \mathrm{serum} \\
\text { cortisol } \leq 330 \mathrm{nmol} / \mathrm{L}\end{array}$ \\
\hline $\begin{array}{l}\text { Moderate CS } \\
\text { Baseline UFC } \\
\leq 5 \times \text { ULN }\end{array}$ & 750 mg/day & $\uparrow 250-500 \mathrm{mg} / \mathrm{day}$ & $\uparrow 250-500 \mathrm{mg} / \mathrm{day}$ & Optimal dose reached \\
\hline $\begin{array}{l}\text { Severe CS } \\
\text { Baseline UFC } \\
>5 \times \text { ULN }\end{array}$ & 1500 mg/day & $\uparrow 500-1000$ mg/day & $\uparrow 500-1000$ mg/day & Optimal dose reached \\
\hline
\end{tabular}

\section{ENDPOINTS}

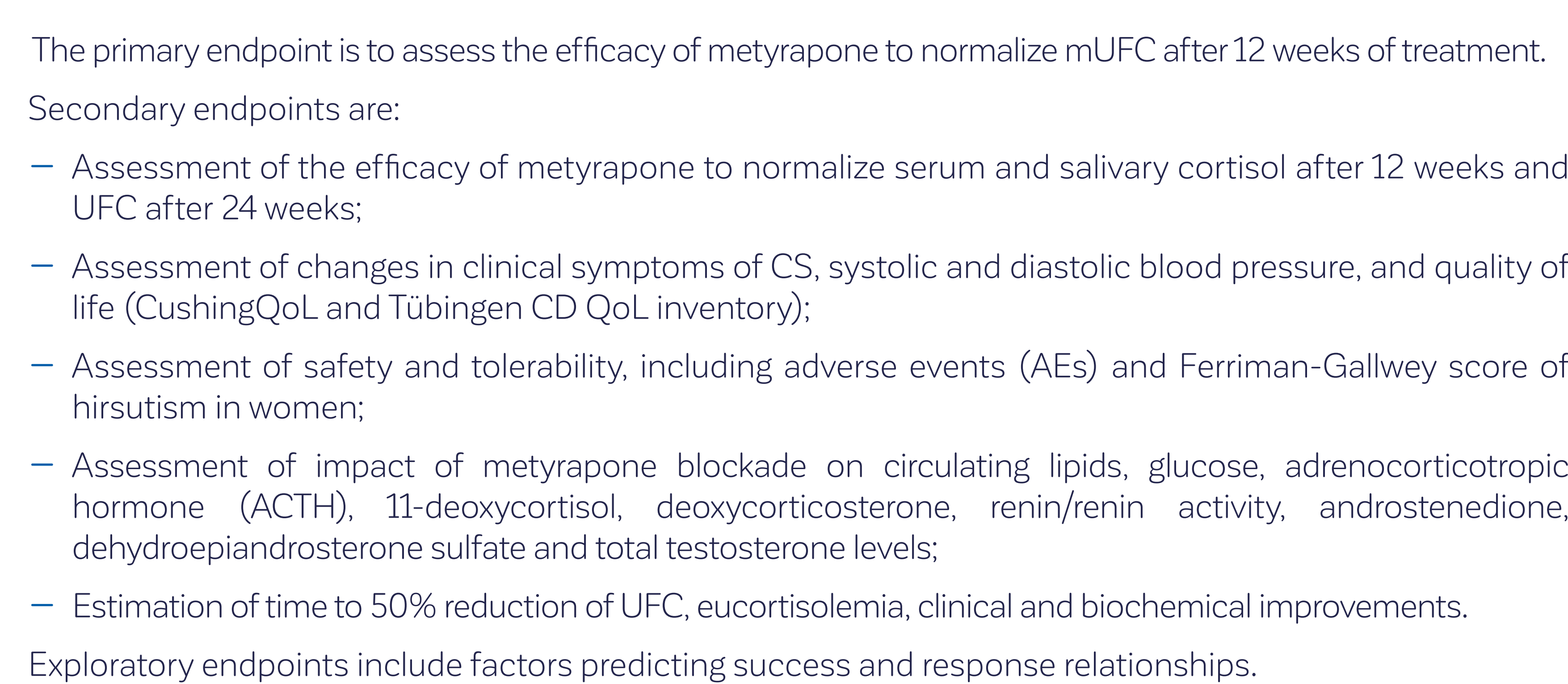

Figure 3: Mean mUFC at baseline and at Week 12 in the initial 28 patients

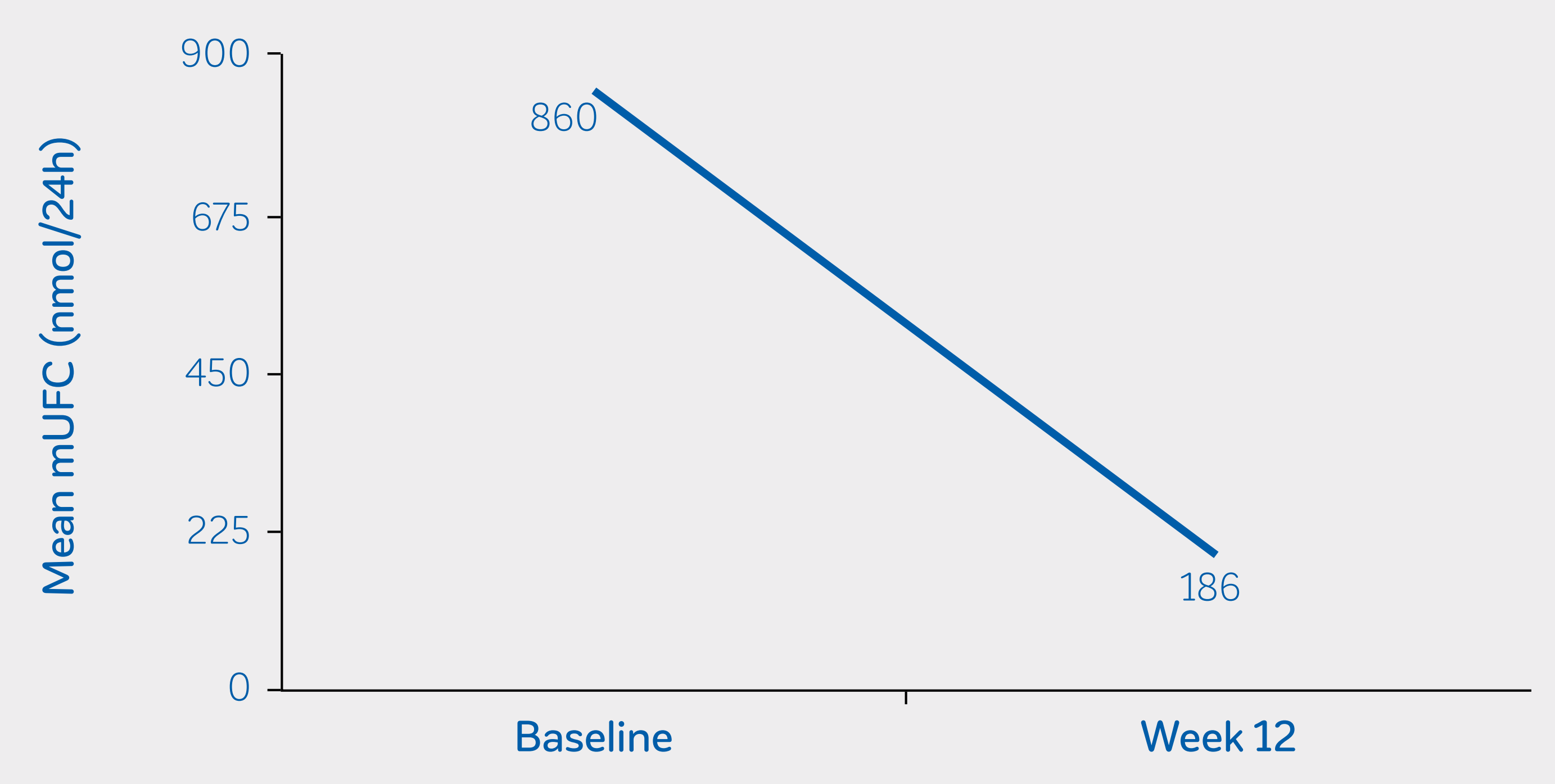

\section{STATUS}

- The study commenced in 2015 and is ongoing.
- By April 2018,35 patients were included: 24 women and 11 men, with a mean age of 45 years old (range: $21-73$ ).
- A total of 32 patients had CD and 21 patients had previously undergone TSS (range: $1-3$ ).
- Nine patients discontinued the study at/or after the primary objective endpoint (Week 12 ) owing to:
inefficacy $(n=3)$, mUFC $>2 \times U L N$ despite improvement by $70 \%(n=1)$, hirsutism ( $n=1)$, serious AEs $(n=1$; severe
hypotension, cellulitis, venous thrombosis and renal insufficiency) and decision to undergo TSS despite
control with metyrapone ( $n=3$ ).
- The mean of the $m U F C$ values in the first 28 patients treated over 12 weeks decreased from $860 \mathrm{nmol} / 24 \mathrm{~h}$
at baseline to $186 \mathrm{nmol} / 24 \mathrm{~h}$ at Week 12 (Figure 3 ).

Acknowledgments and disclosures

B Akinci, A Beckers, M Bolanowski, FA Hanzu, E Mezôsi, A Tönjes, M Boscaro and C Scaroni have each received research grants from HRA Pharma. M Bostnavaron, A Jaspart, and P Borensztein are full-time employees of

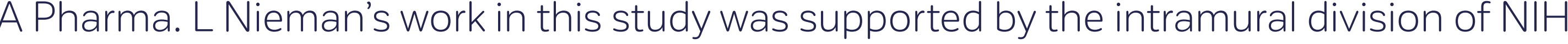

This study and poster were funded by HRA Pharma.

References

https://www.medicines.org.uk/emc/product/4092 (Accessed: April 2018) 